\title{
Assessment of Heavy Metals Pollution in the Sediments of Euphrates River, Iraq
}

\author{
Emad A. Mohammad Salah', Tahseen A. Zaidan², Ahmed S. Al-Rawi ${ }^{2}$ \\ ${ }^{1}$ Department of Applied Geology, College of Science, University of Anbar, Ramadi, Iraq \\ ${ }^{2}$ Department of Chemistry, College of Science, University of Anbar, Ramadi, Iraq \\ Email: ealheety@Yahoo.Com
}

Received September 15, 2012; revised October 19, 2012; accepted October 28, 2012

\begin{abstract}
Fourteen bed sediments samples were collected from the Euphrates River in order to determine concentrations, seasonal, spatial and contamination assessment of heavy metals such as $\mathrm{Pb}, \mathrm{Cd}, \mathrm{Zn}, \mathrm{Cu}, \mathrm{Ni}, \mathrm{Co}, \mathrm{Fe}, \mathrm{Mn}$ and $\mathrm{Cr}$. The mean concentrations are as follows: $2249.47 \mathrm{mg} / \mathrm{kg}$ for Fe, $228.18 \mathrm{mg} / \mathrm{kg}$ for Mn, $67.08 \mathrm{mg} / \mathrm{kg}$ for Ni, $58.4 \mathrm{mg} / \mathrm{kg}$ for Cr, 48.00 $\mathrm{mg} / \mathrm{kg}$ for $\mathrm{Zn}, 28.16 \mathrm{mg} / \mathrm{kg}$ for $\mathrm{Co}, 22.56 \mathrm{mg} / \mathrm{kg}$ for Pb, $18.91 \mathrm{mg} / \mathrm{kg}$ for $\mathrm{Cu}$ and $1.87 \mathrm{mg} / \mathrm{kg}$ for Cd. To assess metal contamination in sediments, sediment quality guidelines were applied. The mean concentration of $\mathrm{Cd}, \mathrm{Cu}, \mathrm{Ni}, \mathrm{Fe}, \mathrm{Mn}$, and $\mathrm{Cr}$ exceeded the USEPA guideline. The metal contamination in the sediments was also evaluated by appling enrichment factor (EF), contamination factor (CF), geo-accumulation index (Igeo) and pollution load index (PLI). Based on enrichment factor (EF), the Euphrates River sediments have very high enrichment for $\mathrm{Pb}$, extremely high for $\mathrm{Cd}$, moderate for $\mathrm{Zn}$, significant to very high for $\mathrm{Ni}$, very high to extremely high for $\mathrm{Co}$, moderate to significant for $\mathrm{Mn}$ and significant to very high for $\mathrm{Cr}$. According to contamination factor (CF), $\mathrm{Cd}$ and $\mathrm{Cr}$ are responsible for very high contamination. According to Igeo, the Euphrates River sediments are moderately to strongly polluted by Cd. Based on PLI, all sampling sites suggest no overall pollution of site quality.
\end{abstract}

Keywords: Heavy Metals; Euphrates; River Sediments; Pollution; Iraq

\section{Introduction}

River sediments are a major carrier of heavy metals in the aquatic environment. Sediments are mixture of several components of mineral species as well as organic debris, represent as ultimate sink for heavy metals discharged into environment $[1,2]$. Chemical leaching of bedrocks, water drainage basins and runoff from banks are the primary sources of heavy metals [3]. Mining operations, disposal of industrial wastes and applications of biocides for pest are other anthropogenic sources [4]. Heavy metals are serious pollutants because of their toxicity, persistence and nondegradability in the environment [5-8]. Polluted sediments, in turn, can act as sources of heavy metals, imparting them into the water and debasing water quality $[9,10]$. To date, many researchers have conducted extensive surveys of heavy metal contamination in sediments [3,11-13]. The results demonstrated that accumulation of heavy metals has occurred in sediments of different regions. Limited surveys have been undertaken to study distribution of heavy metals in the Euphrates River sediments [14-16].

The aim of this work is to assess concentrations of the heavy metals and degree of contamination in the Eu- phrates River sediments.

\section{Materials and Methods}

\subsection{Study Area}

The Euphrates River is one of the most important rivers in the world. Along with the Tigris River, it provided much of the water that supported the development of ancient Mesopotamian culture. Euphrates River rise in the highlands of Turkey and it is formed the Karasu and Murat tributary rivers. Euphrates enters Iraq at AlQaim city. During its passage through Iraq, the river crosses more than $1000 \mathrm{~km}$. The water resources in Iraq are concentrated to the Euphrates and Tigris Rivers. The study area is bounded by latitudes $\left(33^{\circ} 26^{\prime} \mathrm{N}\right.$ to $\left.34^{\circ} 22^{\prime} \mathrm{N}\right)$ and Longitudes $\left(41^{\circ} 8\right.$ ' $\mathrm{N}$ to $\left.43^{\circ} 20^{\prime} \mathrm{E}\right)$, Figure 1. The climate of Iraq in summer, is dry and extremely hot with a shade temperature of $43^{\circ} \mathrm{C}$ during July and August, dropping at night to $26^{\circ} \mathrm{C}$. The winter in Iraq is cold and rainy. Average annual rainfall is estimated at $154 \mathrm{~mm}$ but it ranges from less than $100 \mathrm{~mm}$ in central plain and southern desert in Iraq to $1200 \mathrm{~mm}$ in the north and north-east mountainous regions, which have Mediterranean climate. The climate of the western desert, including the study 


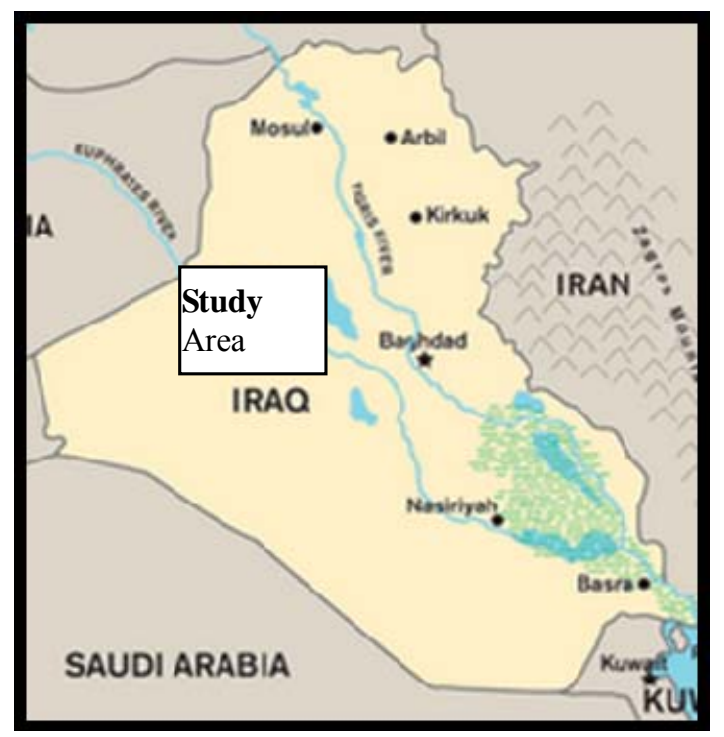

Figure 1. Location map of study area.

area, is characterized by hot summer and cold winter. This region also receives brief violent rainstorms in the winter that usually total of $10 \mathrm{~cm}$ per year.

\subsection{Sampling Collection and Analysis}

Fourteen sampling sites were chosen for collection of sediments along the Euphrates River (Figure 2, Table 1). Sampling sites were localized exactly by GPS (Garmin) locator. Auger tube was used for sediment sampling. The sediments samples were collected in winter and spring 2012. The samples were placed in polyethylene bags and transported to the laboratory under frozen condition (at $4^{\circ} \mathrm{C}$ ). The samples were dried in the laboratory at $104^{\circ} \mathrm{C}$ for forty eight hours, ground to a fine powder and sieved through $106 \mu \mathrm{m}$ stainless steel mesh wire. The samples were then stored in a polyethylene container ready for digestion and analysis. Closed vessel microwave assisted acid digestion technique under high temperature and pressure has become routine [17], which avoids the external contamination and requires shorter time and smaller quantities of acids, thus improving detection limits and overall accuracy of the analytical method [18]. 0.5 gram of sediment sample was put into the reference vessel. Then $25 \mathrm{ml}$ of mixture (HCL: $\left.\mathrm{H}_{2} \mathrm{SO}_{4}: \mathrm{HNO}_{3}, 3: 2: 2\right)$ were added to reaction vessel which was inserted into the microwave unit. The digested solution was cooled and filtered. The filtered sample was then made up to $50 \mathrm{ml}$ with distilled water and stored in a special containers. We used AAS (Atomic Absorption Spectrometry) instrument (Phoenix: 986) to detect and measure heavy metal content in the sediment samples.

\subsection{Assessment of Metal Contamination}

To evaluate the degree of contamination in the sediments,

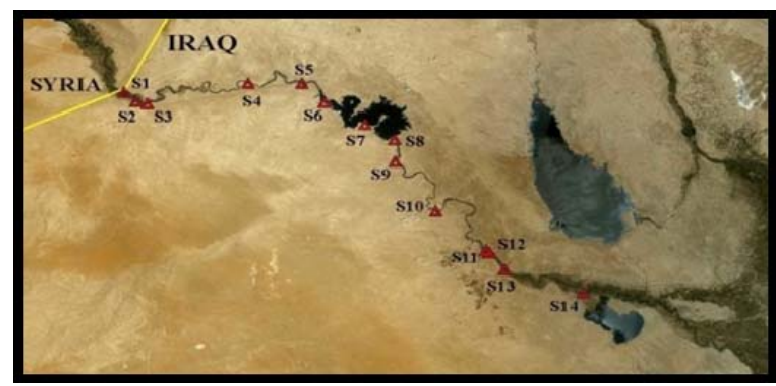

Figure 2. Sampling sites map.

Table 1. Details of sampling locations of Euphrates River.

\begin{tabular}{|c|c|c|c|}
\hline \multirow{2}{*}{$\begin{array}{l}\text { Site } \\
\text { No. }\end{array}$} & \multirow{2}{*}{ Name of Site } & \multicolumn{2}{|c|}{ Location } \\
\hline & & Latitude-N & Longitude-E \\
\hline $\mathrm{S} 1$ & Albagoz & $34^{\circ} 25^{\prime} 22.7^{\prime \prime}$ & $41^{\circ} 01^{\prime} 08.0^{\prime \prime}$ \\
\hline $\mathrm{S} 2$ & Almanee & $34^{\circ} 22^{\prime} 53.6^{\prime \prime}$ & $41^{\circ} 04^{\prime} 23.2^{\prime \prime}$ \\
\hline $\mathrm{S} 3$ & Alphosphate & $34^{\circ} 22^{\prime} 0.39^{\prime \prime}$ & $41^{\circ} 08^{\prime} 02.3^{\prime \prime}$ \\
\hline S4 & Jbab & $34^{\circ} 28^{\prime} 09.1^{\prime \prime}$ & $41^{\circ} 38^{\prime} 29.4^{\prime \prime}$ \\
\hline S5 & Rawa & $34^{\circ} 28^{\prime} 24.2^{\prime \prime}$ & $41^{\circ} 54^{\prime} 38.5^{\prime \prime}$ \\
\hline S6 & Alkaser & $34^{\circ} 22^{\prime} 42.1^{\prime \prime}$ & $42^{\circ} 01^{\prime} 05.9^{\prime \prime}$ \\
\hline S7 & Before Haditha Dam & $34^{\circ} 17^{\prime} 01.5^{\prime \prime}$ & $42^{\circ} 13^{\prime} 22.8^{\prime \prime}$ \\
\hline $\mathrm{S} 8$ & After Haditha Dam & $34^{\circ} 11^{\prime} 30.7^{\prime \prime}$ & $42^{\circ} 22^{\prime} 18.4^{\prime \prime}$ \\
\hline S9 & Hajlan & $34^{\circ} 05^{\prime} 18.6^{\prime \prime}$ & $42^{\circ} 22^{\prime} 08.1^{\prime \prime}$ \\
\hline $\mathrm{S} 10$ & Albaghdadi & $33^{\circ} 51^{\prime} 35.1^{\prime \prime}$ & $42^{\circ} 31^{\prime} 58.4^{\prime \prime}$ \\
\hline S11 & Hit & $33^{\circ} 39^{\prime} 12.0^{\prime \prime}$ & $42^{\circ} 49^{\prime} 01.6^{\prime \prime}$ \\
\hline $\mathrm{S} 12$ & Aldowara & $33^{\circ} 38^{\prime} 27.3^{\prime \prime}$ & $42^{\circ} 49^{\prime} 59.9^{\prime \prime}$ \\
\hline S13 & Almohamadi & $33^{\circ} 33^{\prime} 51.3^{\prime \prime}$ & $42^{\circ} 45^{\prime} 07.3^{\prime \prime}$ \\
\hline S14 & Ramadi & $33^{\circ} 26^{\prime} 23.3^{\prime \prime}$ & $43^{\circ} 17^{\prime} 53.5^{\prime \prime}$ \\
\hline
\end{tabular}

we used four parameters: Enrichment Factor (EF), Contamination Factor (CF), Pollution Load Index (PLI) and Geo-accumulation Index $\left(\mathrm{I}_{\text {geo }}\right)$.

Enrichment Factor (EF)

The enrichment factor (EF) of metals is a useful indicator reflecting the status and degree of environmental contamination [19]. The EF calculations compare each value with a given background level, either from the local site, using older deposits formed under similar conditions, but without anthropogenic impact, or from a regional or global average composition [20,21]. The EF was calculated using the method proposed by [22] as follows:

$$
\mathrm{EF}=(\mathrm{Me} / \mathrm{Fe})_{\text {sample }} /(\mathrm{Me} / \mathrm{Fe})_{\text {background }}
$$

where $(\mathrm{Me} / \mathrm{Fe})$ sample is the metal to $\mathrm{Fe}$ ratio in the sample of interest; (Me/Fe)background is the natural 
background value of metal to Fe ratio. As we do not have metal background values for our study area, we used the values from surface world rocks [23]. Iron was chosen as the element of normalization because natural sources $(1.5 \%)$ vastly dominate its input [24]. Enrichment factor categories are listed in Table 2.

Contamination Factor (CF)

The level of contamination of sediment by metal is expressed in terms of a contamination factor (CF) calculated as:

$$
\mathrm{CF}=\mathrm{C}_{\mathrm{m}} \text { Sample } / \mathrm{C}_{\mathrm{m}} \text { Background }
$$

where, $\mathrm{C}_{\mathrm{m}}$ Sample is the concentration of a given metal in river sediment, and $\mathrm{C}_{\mathrm{m}}$ Background is value of the metal equals to the world surface rock average given by [23]. CF values for describing the contamination level are shown in Table 3.

Pollution Load Index (PLI)

Pollution load index (PLI), for a particular site, has been evaluated following the method proposed by [25]. This parameter is expressed as:

$$
\mathrm{PLI}=\left(\mathrm{CF}_{1} \times \mathrm{CF}_{2} \times \mathrm{CF}_{3} \times \cdots \mathrm{CF}_{\mathrm{n}}\right)^{1 / \mathrm{n}}
$$

where, $\mathrm{n}$ is the number of metals.

Geo-accumulation Index ( $\left.\mathrm{I}_{\text {geo }}\right)$

Enrichment of metal concentration above baseline concentrations was calculated using the method proposed by [26], termed the geo-accumulation index $\left(\mathrm{I}_{\mathrm{geo}}\right)$. Geoaccumulation index is expressed as follows:

$$
\mathrm{I}_{\mathrm{geo}}=\log _{2}\left[\mathrm{C}_{\mathrm{m}} \text { Sample } /\left(1.5 \times \mathrm{C}_{\mathrm{m}} \text { Background }\right)\right]
$$

where $C_{m}$ Sample is the measured concentration of element $\mathrm{n}$ in the sediment sample and $\mathrm{B}_{\mathrm{m}}$ Background is the geochemical background value (world surface rock average given by [23]). The factor 1.5 is introduced to include possible variation of the background values due to lithogenic effect. Muller [27] proposed seven grades or classes of the geo-accumulation index. These classes are given in Table 4. The overall total geo-accumulation index $\left(\mathrm{I}_{\text {tot }}\right)$ is defined as the sum of $\mathrm{I}_{\mathrm{geo}}$ for all trace elements obtain from the site [28]. The number of toxic elements determined in a sediment sample and their respective $\mathrm{I}_{\text {geo }}$ value would influence the $\mathrm{I}_{\text {tot }}$.

Table 2. Enrichment factor (EF) categories ( Mmolawa et al. 2011).

\begin{tabular}{cc}
\hline $\begin{array}{c}\text { Enrichment factor } \\
(\mathrm{EF})\end{array}$ & Enrichment factor (EF) Categories \\
\hline $\mathrm{EF}<2$ & Deficiency to minimal enrichment \\
$2 \leq \mathrm{EF}<5$ & Moderate enrichment \\
$5 \leq \mathrm{EF}<20$ & Significant enrichment \\
$20 \leq \mathrm{EF}<40$ & Very high enrichment \\
$\mathrm{EF} \geq 40$ & Extremely high enrichment \\
\hline
\end{tabular}

Table 3. Contamination factor (CF) and level of contamination (Hakanson, 1980).

\begin{tabular}{cc}
\hline $\begin{array}{c}\text { Contamination Factor } \\
(\mathrm{CF})\end{array}$ & Contamination Level \\
\hline $\mathrm{CF}<1$ & Low contamination \\
$1 \leq \mathrm{CF}<3$ & Moderate contamination \\
$3 \leq \mathrm{CF}<6$ & Considerable contamination \\
$\mathrm{CF}>6$ & Very high contamination \\
\hline
\end{tabular}

Table 4. Muller's classification for geo-accumulation index ( $\left.\mathrm{I}_{\text {geo }}\right)$.

\begin{tabular}{ccc}
\hline $\mathrm{I}_{\text {geo }}$ Value & Class & Sediment Quality \\
\hline$\leq 0$ & 0 & Unpolluted \\
$0-1$ & 1 & From unpolluted to moderately polluted \\
$1-2$ & 2 & Moderately polluted \\
$2-3$ & 3 & From moderately to strongly polluted \\
$3-4$ & 4 & Strongly polluted \\
$4-5$ & 5 & From strongly to extremely polluted \\
$>6$ & 6 & Extremely \\
\hline
\end{tabular}

\section{Results and Discussion}

The descriptive statistics of the data set pertaining to the Euphrates River sediments, geochemical background concentration and sediment quality guidelines are presented in Table 5. Intermetallic correlation, seasonal and spatial variations were delineated in Table 6 and shown in Figures 3 and 4. Results of this study were compared with the other previous local and global studies, Table 7.

The enrichment factor (EF) is a convenient measure of geochemical trends and is used for making comparisons between areas [22]. The EF values of heavy metals in the Euphrates River sediments were listed and Table 8 and shown in Figure 5.

The contamination factor (CF) was used to determine the contamination status of sediments of Euphrates River. The calculated CF for various heavy metals in sediments of Euphrates River is presented in Table 9 and shown in Figure 6.

The PLI provides simple but comparative means for assessing a site quality, where a value of PLI $<1$ denotes perfection; PLI $=1$ presents that only baseline levels of pollutants are presented and PLI $>1$ would indicate deterioration of site quality [25]. The PLI values for heavy metals in the Euphrates River sediments are listed in Table 10 and shown in Figure 7.

The geo-accumulation index ( $\left.\mathrm{I}_{\text {geo }}\right)$ was used to determine the pollution level of sediments. The calculated $\mathrm{I}_{\text {geo }}$ values, based on the world surface rock average, are presented in 
Table 5. Concentration of heavy metals in the sediments samples of Euphrates river during the study period.

\begin{tabular}{|c|c|c|c|c|c|c|c|c|c|}
\hline \multirow[b]{2}{*}{ Metal } & \multirow[b]{2}{*}{ Minimum } & \multirow[b]{2}{*}{ Maximum } & \multirow[b]{2}{*}{ Mean } & \multirow[b]{2}{*}{$\begin{array}{l}\text { Standard } \\
\text { deviation }\end{array}$} & \multicolumn{2}{|c|}{ Geochemical Background } & \multirow[b]{2}{*}{$\begin{array}{l}\mathrm{WHO}^{3} \\
\mathrm{SQG}^{*}\end{array}$} & \multirow[b]{2}{*}{$\begin{array}{l}\text { USEPA }^{4} \\
\text { SQG }^{*}\end{array}$} & \multirow[b]{2}{*}{$\begin{array}{l}\mathrm{CCME}^{*} \\
\mathrm{SQG}^{*}\end{array}$} \\
\hline & & & & & $\begin{array}{c}\text { World }^{1} \\
\text { surface rock } \\
\text { average }\end{array}$ & $\begin{array}{l}\text { Mean shale } \\
\text { concentration }\end{array}$ & & & \\
\hline $\mathrm{Pb}$ & 8.02 & 32.69 & 22.56 & 7.37 & 16 & 20 & - & 40 & 35 \\
\hline $\mathrm{Cd}$ & 0.87 & 2.35 & 1.87 & 0.45 & 0.2 & 0.3 & 6 & 0.6 & 0.6 \\
\hline $\mathrm{Zn}$ & 14.96 & 130.25 & 48.00 & 31.25 & 127 & 95 & 123 & 110 & 123 \\
\hline $\mathrm{Cu}$ & 10.35 & 30.52 & 18.91 & 5.59 & 32 & 11.2 & 25 & 16 & 35.7 \\
\hline $\mathrm{Ni}$ & 39.98 & 103.98 & 67.08 & 19.36 & 49 & 68 & 20 & 16 & - \\
\hline Co & 21.88 & 38.73 & 28.16 & 4.91 & 13 & 29 & - & - & - \\
\hline $\mathrm{Fe}$ & 928.7 & 3441.05 & 2249.47 & 571.18 & 35900 & 46700 & - & 30 & - \\
\hline $\mathrm{Mn}$ & 136.05 & 312.11 & 228.18 & 56.13 & 750 & 850 & - & 30 & - \\
\hline $\mathrm{Cr}$ & 36.45 & 120.11 & 58.40 & 21.73 & 71 & 90 & 25 & 25 & 37.3 \\
\hline
\end{tabular}

Values are in milligram per Kilogram (mg/kg); ${ }^{1}$ Martin and Meybeck [23]; ${ }^{2}$ Venkatesha Raju [3]; ${ }^{3}$ WHO [32]; ${ }^{4}$ USEPA [33]; ${ }^{5} \mathrm{CCME}[17] ;{ }^{*}$ Sediment quality guidelines.

Table 6. Pearson's correlation coefficient of heavy metals in Euphrates River sediments.

\begin{tabular}{ccccccccc}
\hline Metal & $\mathrm{Pb}$ & $\mathrm{Cd}$ & $\mathrm{Zn}$ & $\mathrm{Cu}$ & $\mathrm{Ni}$ & $\mathrm{Co}$ & $\mathrm{Fe}$ & $\mathrm{Mn}$ \\
\hline $\mathrm{Pb}$ & 1.000 & & & & & & \\
$\mathrm{Cd}$ & 0.436 & 1.000 & & & & & & \\
$\mathrm{Zn}$ & 0.515 & 0.374 & 1.000 & & & & & \\
$\mathrm{Cu}$ & 0.519 & $\mathbf{0 . 5 9 8}$ & $\mathbf{0 . 7 5 8}$ & 1.000 & & & & \\
$\mathrm{Ni}$ & 0.380 & 0.487 & 0.387 & $\mathbf{0 . 6 8 3}$ & 1.000 & & & \\
$\mathrm{Co}$ & 0.472 & 0.032 & 0.577 & 0.234 & 0.053 & 1.000 & & \\
$\mathrm{Fe}$ & $\mathbf{0 . 6 1 0}$ & 0.522 & $\mathbf{0 . 5 9 5}$ & $\mathbf{0 . 6 1 7}$ & 0.318 & 0.084 & 1.000 & \\
$\mathrm{Mn}$ & 0.047 & $\mathbf{0 . 6 9 9}$ & -0.086 & 0.401 & 0.342 & -0.485 & 0.208 & 1.00 \\
$\mathrm{Cr}$ & 0.441 & $\mathbf{0 . 5 8 0}$ & $\mathbf{0 . 8 0 8}$ & $\mathbf{0 . 5 7 4}$ & 0.421 & $\mathbf{0 . 6 6 8}$ & 0.451 & -0.035 \\
\hline
\end{tabular}

Marked correlations are significant at $\mathrm{p}<0.05$.

Table 11 and the variations are shown in Figure 8.

The concentration of $\mathrm{Pb}$ varied from 8.02 to 32.69 $\mathrm{mg} / \mathrm{kg}$, and mean value was $22.56 \mathrm{mg} / \mathrm{kg}$. It was more than the world surface rock average and the shale concentration as a background level. In comparison with sediment quality guideline, the mean value did not exceed the limits, and this result shows that the Euphrates River sediments are not polluted by $\mathrm{Pb}$. $\mathrm{Pb}$ expressed a strong positive correlation with $\mathrm{Fe}$ at 0.05 level. The strong correlation indicates that the two elements have common sources. In general, $\mathrm{Pb}$ concentrations in sediments were high during the spring than winter (Figure 3(a)). $\mathrm{Pb}$ concentration varies between $8.02 \mathrm{mg} / \mathrm{kg}$ at $\mathrm{S} 6$ and $32.69 \mathrm{mg} / \mathrm{kg}$ at $\mathrm{S} 1$, Figure 4(a). High values of $\mathrm{Pb}$ concentration at S7, S8 (Haditha Dam), S12 (Heet city) and S14 (Ramadi city) as well as S1 (AlQaim city) might be due to increased human activity since these are township areas. $\mathrm{Pb}$ concentration was in a good agreement to that reported in study of [14] for the upper region of Euphrates River (same study area) and study of [29] for the Euphrates River profile in Iraq (Table 7). It was less than that recorded by [15] for two stations in Heet and Ramadi cities. It was also less than the world rivers average [23].

The EF values for $\mathrm{Pb}$ in Euphrates River sediments were ranged from 9.35 to 35.97. The EF values for $\mathrm{Pb}$ were found to be greater than 20 in most of sampling sites (Table 8), suggesting that these sites are classified as very high enrichment for $\mathrm{Pb}$. Rabee et al. [15] found that the $\mathrm{EF}$ values for $\mathrm{Pb}$ in two stations in Heet and Ramadi cities are 5.4 and 6.20, respectively. They classified these stations as significant enrichment for $\mathrm{Pb}$. The 
Table 7. Concentrations of heavy metals in the Euphrates river sediments (in $\mathrm{mg} / \mathrm{kg}$ ) in comparison to other local studies, for other rivers and world river sediments averages.

\begin{tabular}{|c|c|c|c|c|c|c|c|c|c|c|}
\hline $\begin{array}{l}\text { River/Date of } \\
\text { sampling/ } \\
\text { Location }\end{array}$ & $\mathrm{Pb}$ & $\mathrm{Cd}$ & $\mathrm{Zn}$ & $\mathrm{Cu}$ & $\mathrm{Ni}$ & $\mathrm{Co}$ & $\mathrm{Fe}$ & $\mathrm{Mn}$ & $\mathrm{Cr}$ & Reference \\
\hline $\begin{array}{l}\text { Euphrates } \\
1997 \text { Iraq }\end{array}$ & 19.5 & 0.08 & 30 & 24.6 & 125 & - & - & 450 & - & [14] \\
\hline $\begin{array}{l}\text { Euphrates } \\
2008 \text { Iraq }\end{array}$ & 39.1 & 0.73 & - & 46.6 & 29.1 & - & - & 302.75 & - & [15] \\
\hline $\begin{array}{c}\text { Euphrates } \\
1998 \text { Iraq }\end{array}$ & 19.5 & 3.6 & 91.16 & 45.25 & 182.91 & 48.6 & - & - & 119.4 & [29] \\
\hline $\begin{array}{c}\text { Euphrates } \\
\text { 2004-2005 } \\
\text { Iraq }\end{array}$ & 0.59 & 11.2 & 67.66 & 14.14 & 0.37 & 8.24 & 661.7 & 37.7 & 0.47 & [16] \\
\hline Tigris Iraq & 43.4 & - & 54.6 & 25.5 & 155.3 & 44.9 & - & - & 865.4 & [34] \\
\hline $\begin{array}{c}\text { Tigris } 1993 \\
\text { Iraq }\end{array}$ & $17.9-30.6$ & $0.1-1.7$ & $8.3-47.1$ & $17.4-28.9$ & $105.4-125.5$ & - & - & $451.3-565.6$ & - & [35] \\
\hline $\begin{array}{c}\text { Tigris } \\
2008 \text { Iraq }\end{array}$ & $7-90$ & $0.3-1.3$ & - & $5-55$ & $6-30$ & - & - & $166-426$ & - & [36] \\
\hline $\begin{array}{l}\text { Yangtze } \\
2005 \text { China }\end{array}$ & 49.19 & 0.98 & 230.39 & 60.03 & 41.86 & & & & 108.00 & [13] \\
\hline Tapti India & - & - & $1.17-6.06$ & $0.52-4.07$ & - & - & $1.88-5.71$ & $6-8.9$ & - & [37] \\
\hline $\begin{array}{l}\text { Buriganga } \\
\text { Bangladesh }\end{array}$ & 79.8 & 0.8 & 502.3 & 184.4 & - & - & - & - & 101.2 & [38] \\
\hline $\begin{array}{c}\text { Cauvery } \\
2007-2009 \\
\text { India }\end{array}$ & 4.3 & 1.3 & 93.1 & 11.2 & 27.7 & 1.9 & 11144 & 176.3 & 38.9 & {$[3]$} \\
\hline World average & 230.75 & 1.4 & 303 & 122.9 & 102.1 & 55.3 & 57405.9 & 975.3 & 126 & [23] \\
\hline
\end{tabular}

Table 8. Enrichment ratio (ER) values of heavy metals in Euphrates river sediments.

\begin{tabular}{|c|c|c|c|c|c|c|c|c|}
\hline $\begin{array}{l}\text { Sampling } \\
\text { Site }\end{array}$ & $\mathrm{Pb}$ & $\mathrm{Cd}$ & $\mathrm{Zn}$ & $\mathrm{Cu}$ & $\mathrm{Ni}$ & Co & $\mathrm{Mn}$ & $\mathrm{Cr}$ \\
\hline S1 & 26.92 & 143.23 & 5.06 & 8.93 & 26.29 & 33.27 & 4.69 & 13.77 \\
\hline S2 & 16.66 & 167.90 & 5.37 & 12.51 & 33.61 & 26.66 & 6.28 & 11.84 \\
\hline S3 & 24.59 & 189.95 & 4.97 & 11.97 & 31.00 & 30.18 & 6.34 & 11.48 \\
\hline S4 & 24.84 & 183.99 & 4.61 & 9.70 & 18.15 & 34.87 & 7.09 & 11.46 \\
\hline S5 & 21.05 & 157.96 & 5.47 & 10.57 & 18.42 & 28.82 & 6.28 & 10.42 \\
\hline S6 & 9.35 & 141.84 & 2.43 & 6.64 & 15.22 & 39.42 & 4.94 & 13.87 \\
\hline S7 & 35.97 & 176.22 & 4.53 & 9.95 & 20.88 & 49.01 & 4.60 & 14.47 \\
\hline S8 & 18.60 & 80.33 & 4.73 & 6.79 & 13.15 & 20.88 & 2.56 & 6.04 \\
\hline S9 & 30.82 & 168.15 & 4.55 & 12.50 & 48.40 & 90.60 & 7.01 & 19.84 \\
\hline S10 & 27.82 & 103.70 & 7.55 & 9.02 & 19.62 & 38.58 & 3.91 & 11.20 \\
\hline S11 & 21.62 & 172.13 & 3.44 & 5.61 & 19.54 & 27.69 & 4.48 & 14.52 \\
\hline $\mathrm{S} 12$ & 22.72 & 145.53 & 10.87 & 9.34 & 20.26 & 34.60 & 4.01 & 15.78 \\
\hline S13 & 15.77 & 164.02 & 4.81 & 9.16 & 14.82 & 35.04 & 5.59 & 12.39 \\
\hline S14 & 23.12 & 146.61 & 12.90 & 12.00 & 22.27 & 37.49 & 3.23 & 21.28 \\
\hline
\end{tabular}


Table 9. Contamination factor (CF) for the heavy metals of Euphrates River sediments.

\begin{tabular}{|c|c|c|c|c|c|c|c|c|c|}
\hline $\begin{array}{l}\text { Sampling } \\
\text { Sites }\end{array}$ & $\mathrm{Pb}$ & $\mathrm{Cd}$ & $\mathrm{Zn}$ & $\mathrm{Cu}$ & $\mathrm{Ni}$ & Co & $\mathrm{Fe}$ & $\mathrm{Mn}$ & $\mathrm{Cr}$ \\
\hline S1 & 2.04 & 10.45 & 0.37 & 0.65 & 1.93 & 2.42 & 0.072 & 0.342 & 1.00 \\
\hline S2 & 1.05 & 10.6 & 0.34 & 0.78 & 2.12 & 1.68 & 0.063 & 0.396 & 0.74 \\
\hline S3 & 1.43 & 11.05 & 0.29 & 0.69 & 1.80 & 1.75 & 0.058 & 0.374 & 0.66 \\
\hline S4 & 1.43 & 10.65 & 0.26 & 0.56 & 1.05 & 2.01 & 0.057 & 0.410 & 0.66 \\
\hline S5 & 1.39 & 10.45 & 0.36 & 0.69 & 1.21 & 1.90 & 0.066 & 0.416 & 0.68 \\
\hline S6 & 0.50 & 7.6 & 0.13 & 0.35 & 0.81 & 2.11 & 0.053 & 0.266 & 0.74 \\
\hline S7 & 2.01 & 9.85 & 0.25 & 0.55 & 1.16 & 2.74 & 0.055 & 0.257 & 0.80 \\
\hline S8 & 1.78 & 7.7 & 0.45 & 0.65 & 1.26 & 2.00 & 0.095 & 0.245 & 0.57 \\
\hline S9 & 0.79 & 4.35 & 0.11 & 0.32 & 1.25 & 2.34 & 0.025 & 0.181 & 0.51 \\
\hline S10 & 1.47 & 5.5 & 0.40 & 0.47 & 1.04 & 2.04 & 0.053 & 0.207 & 0.59 \\
\hline S11 & 1.47 & 11.75 & 0.23 & 0.38 & 1.33 & 1.89 & 0.068 & 0.306 & 0.99 \\
\hline $\mathrm{S} 12$ & 1.63 & 10.45 & 0.78 & 0.67 & 1.45 & 2.48 & 0.071 & 0.288 & 1.13 \\
\hline S13 & 0.87 & 9.05 & 0.26 & 0.50 & 0.94 & 1.93 & 0.055 & 0.308 & 0.68 \\
\hline S14 & 1.83 & 11.65 & 1.02 & 0.95 & 1.77 & 2.97 & 0.079 & 0.257 & 1.69 \\
\hline Mean & 1.40 & 9.36 & 0.37 & 0.58 & 1.36 & 2.16 & 0.062 & 0.30 & 0.81 \\
\hline
\end{tabular}

Table 10. Geo-accumulation indices $\left(\mathrm{I}_{\text {geo }}\right)$ of heavy metals in Euphrates River sediments.

\begin{tabular}{|c|c|c|c|c|c|c|c|c|c|c|}
\hline $\begin{array}{l}\text { Sampling } \\
\text { Sites }\end{array}$ & $\mathrm{Pb}$ & $\mathrm{Cd}$ & $\mathrm{Zn}$ & $\mathrm{Cu}$ & $\mathrm{Ni}$ & $\mathrm{Co}$ & $\mathrm{Fe}$ & $\mathrm{Mn}$ & $\mathrm{Cr}$ & $\mathrm{I}_{\text {tot }}$ \\
\hline S1 & 0.44 & 2.79 & -2.05 & -1.21 & 0.35 & 0.69 & -4.36 & -2.13 & -0.57 & -6.05 \\
\hline S2 & -0.51 & 2.81 & -2.18 & -0.94 & 0.49 & 0.16 & -4.57 & -1.92 & -1.00 & -7.66 \\
\hline $\mathrm{S} 3$ & -0.07 & 2.87 & -2.39 & -1.12 & 0.26 & 0.22 & -4.70 & -2.00 & -1.16 & -8.09 \\
\hline S4 & -0.06 & 2.82 & -2.55 & -1.43 & -0.51 & 0.42 & -4.69 & -1.87 & -1.17 & -9.04 \\
\hline S5 & -0.10 & 2.79 & -2.05 & -1.12 & -0.30 & 0.34 & -4.50 & -1.85 & -1.12 & -7.91 \\
\hline S6 & -1.60 & 2.33 & -3.64 & -2.12 & -0.88 & 0.49 & -4.80 & -2.49 & -1.01 & -13.72 \\
\hline S7 & 0.42 & 2.71 & -2.55 & -1.43 & -0.37 & 0.86 & -4.74 & -2.54 & -0.89 & -8.53 \\
\hline S8 & 0.25 & 2.35 & -1.73 & -1.21 & -0.25 & 0.41 & -3.96 & -2.61 & -1.37 & -8.12 \\
\hline S9 & -0.91 & 1.53 & -3.83 & -2.25 & -0.26 & 0.64 & -5.86 & -3.05 & -1.54 & -15.52 \\
\hline S10 & -0.03 & 1.87 & -1.94 & -1.68 & -0.53 & 0.44 & -4.82 & -2.85 & -1.33 & -10.87 \\
\hline S11 & -0.03 & 2.96 & -2.73 & -2.00 & -0.18 & 0.33 & -4.45 & -2.29 & -1.39 & -9.78 \\
\hline $\mathrm{S} 12$ & 0.11 & 2.79 & -0.94 & -1.18 & -0.04 & 0.72 & -4.38 & -2.38 & -0.40 & -5.70 \\
\hline $\mathrm{S} 13$ & -0.78 & 2.59 & -2.55 & -1.59 & -0.68 & 0.36 & -4.76 & -2.28 & -1.13 & -10.82 \\
\hline S14 & 0.28 & 2.95 & -0.55 & -0.66 & 0.85 & 0.98 & -4.24 & -2.54 & 0.17 & -2.76 \\
\hline
\end{tabular}


Table 11. Pollution load index (PLI) values for heavy metals in Euphrates River sediments.

\begin{tabular}{lc}
\hline PLI & $\begin{array}{c}\text { Sampling } \\
\text { Sites }\end{array}$ \\
\hline 0.94 & S1 \\
0.83 & S2 \\
0.80 & S3 \\
0.74 & S4 \\
0.81 & S5 \\
0.52 & S6 \\
0.77 & S7 \\
0.79 & S8 \\
0.45 & S9 \\
0.64 & S10 \\
0.75 & S11 \\
0.96 & S12 \\
0.65 & S13 \\
1.15 & S14 \\
\hline
\end{tabular}
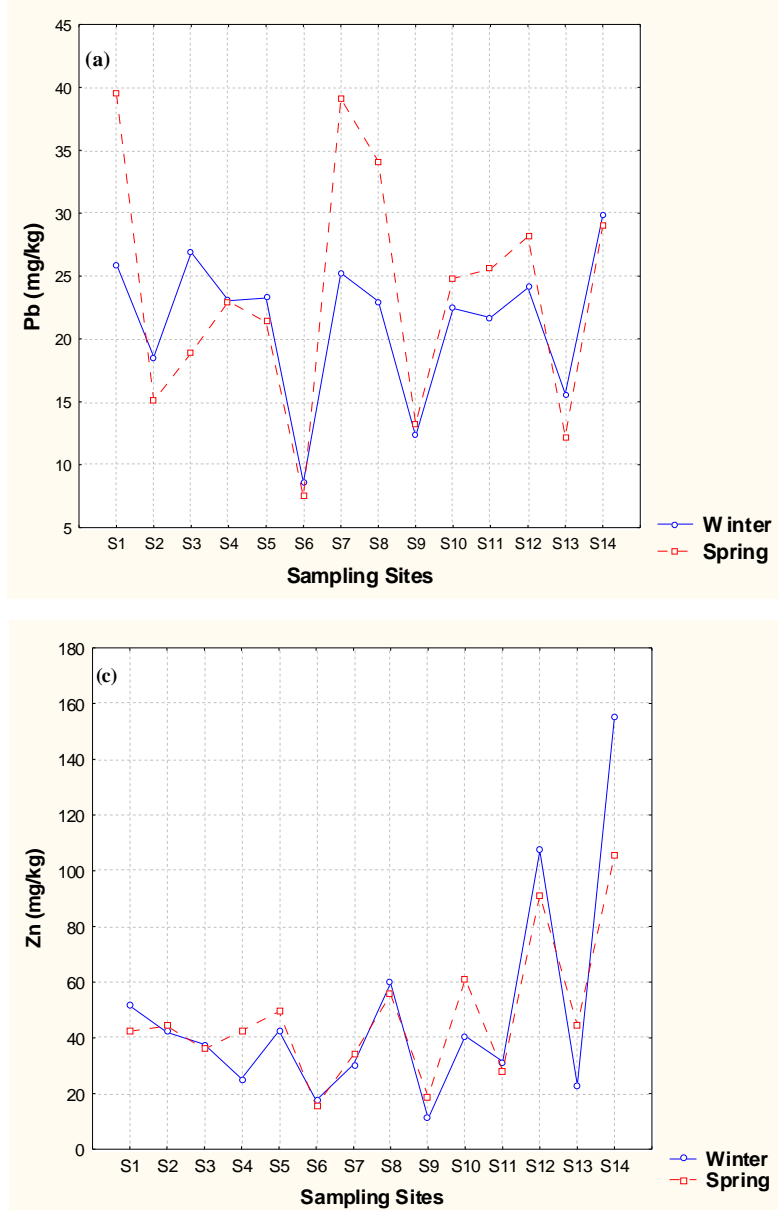

$\mathrm{CF}$ values for $\mathrm{Pb}$ in Euphrates River sediments varied from 0.50 to 2.04 with a mean value of 1.4 , Table 9 . Most sampling sites has CF greater than 1 and less than 3 . It was found that most sampling sites were moderately contaminated by $\mathrm{Pb}$ except $\mathrm{S} 6, \mathrm{~S} 9$ and $\mathrm{S} 13$ face low contamination (Table 3 ). The $\mathrm{I}_{\text {geo }}$ values for $\mathrm{Pb}$ in majority of sampling sites were less than $0(<0)$, except S1, S7 and S14 were less than $1(<1)$, Table 10. According to Muller's classification (Table 4), the calculated $I_{\text {geo }}$ values for $\mathrm{Pb}$ indicate sediment quality be considered as polluted for majority of sites and from unpolluted to moderately polluted for S1, S7 and S14.

$\mathrm{Cd}$ concentration varied between 0.87 and $2.35 \mathrm{mg} / \mathrm{kg}$ and mean value was $1.87 \mathrm{mg} / \mathrm{kg}$. It was more than the world surface rock average and the mean shale concentration as a geochemical background level (Table 5). The mean value of $\mathrm{Cd}$ concentration did not exceed the WHO sediment quality guidelines and exceeded the USEPA guidelines. According to USEPA, Euphrates River sediments were polluted by $\mathrm{Cd}$. Generally, Cd concentrations were highest during spring at downstream sites and highest during winter at upstream sites, Figure 3(b). The mean value of $\mathrm{Cd}$ concentration has strong positive correlation with $\mathrm{Mn}$ at 0.05 level. It has also good positive
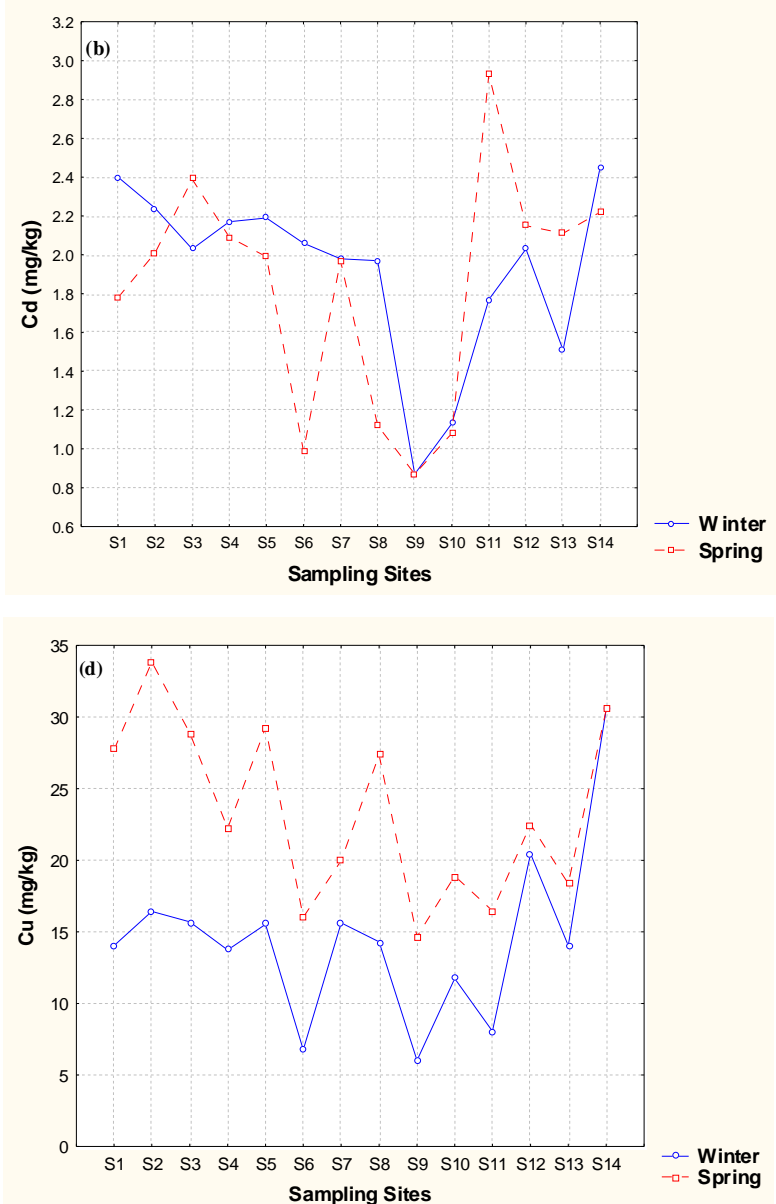

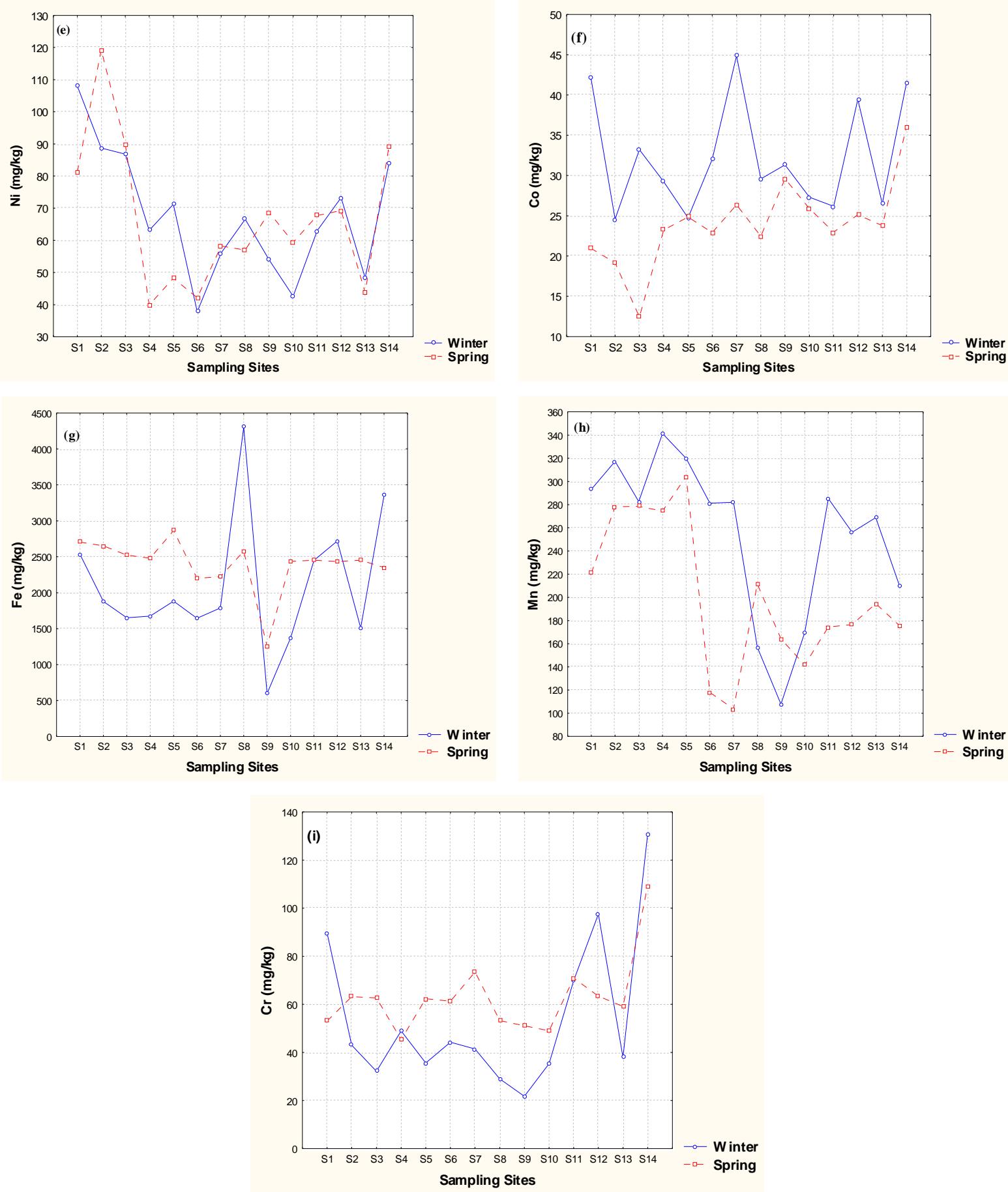

Figure 3. Seasonal and spatial variations of heavy metals in Euphrates River sediments.

correlation with $\mathrm{Cu}$ and $\mathrm{Cr}$ at 0.05 level. The good and strong positive correlations indicate that these heavy metals have common contamination sources. Spatial variation of $\mathrm{Cd}$ concentration was given in Figure 4(b), the maximum value was $2.35 \mathrm{mg} / \mathrm{kg}$ at S11and the minimum value was $0.87 \mathrm{mg} / \mathrm{kg}$ at S9. High values, were recorded at S3 (near Phosphate Factory), S11 (Heet city) and S14 (Ramadi city). These high values may be attrib- uted to the anthropogenic activities such as urbanization, industrialization and agricultural runoff. The mean value of $\mathrm{Cd}$ concentration was more than that assessed by [14] and by [15]. It was also more than that of the world rivers average [23]. It was less than that reported by [29]. AlBassam [30] suggested that anthropogenic sources may have significant role in the enrichment of $\mathrm{Cd}$ in the Euphrates River sediments. These sources include discharging of 


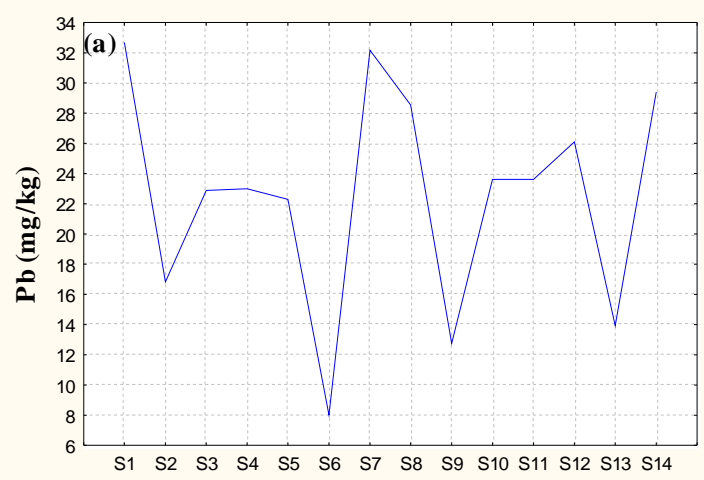

Sampling Sites

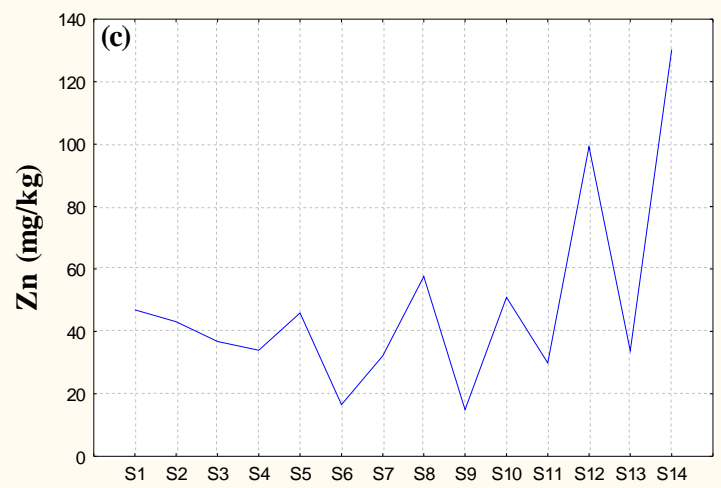

Sampling Sites
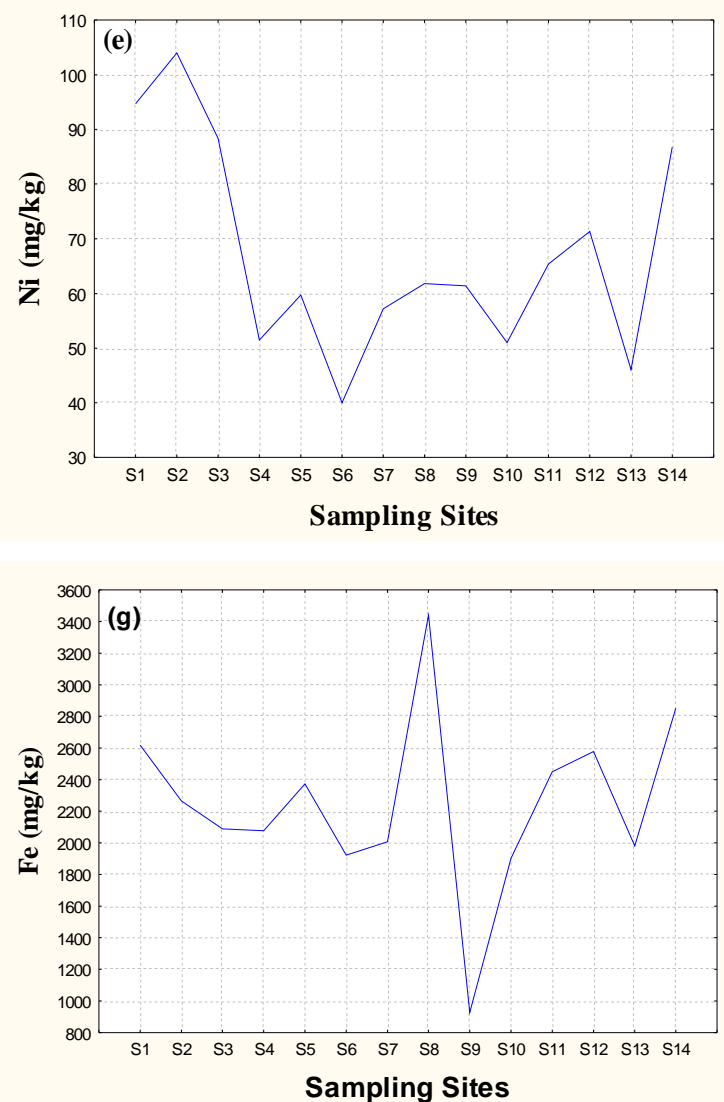

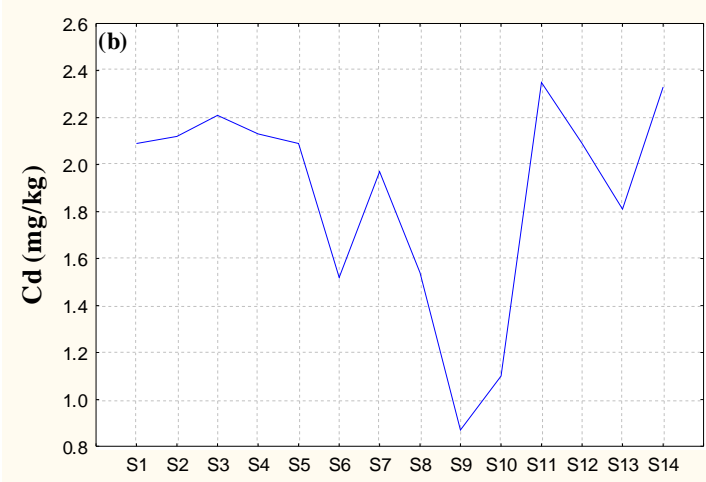

Sampling Sites

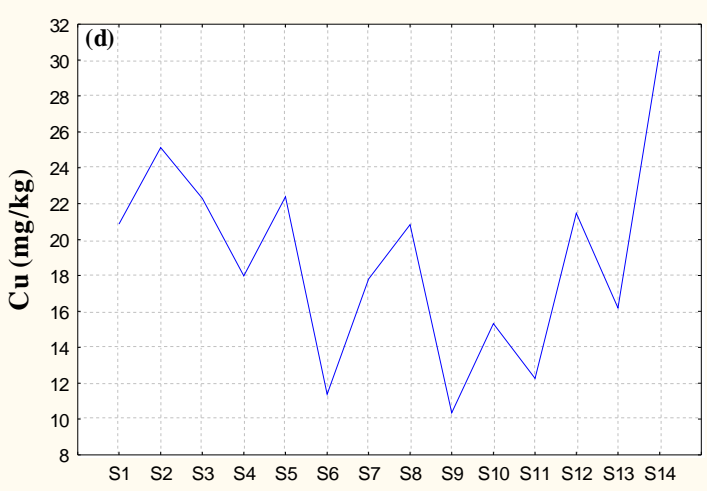

Sampling Sites
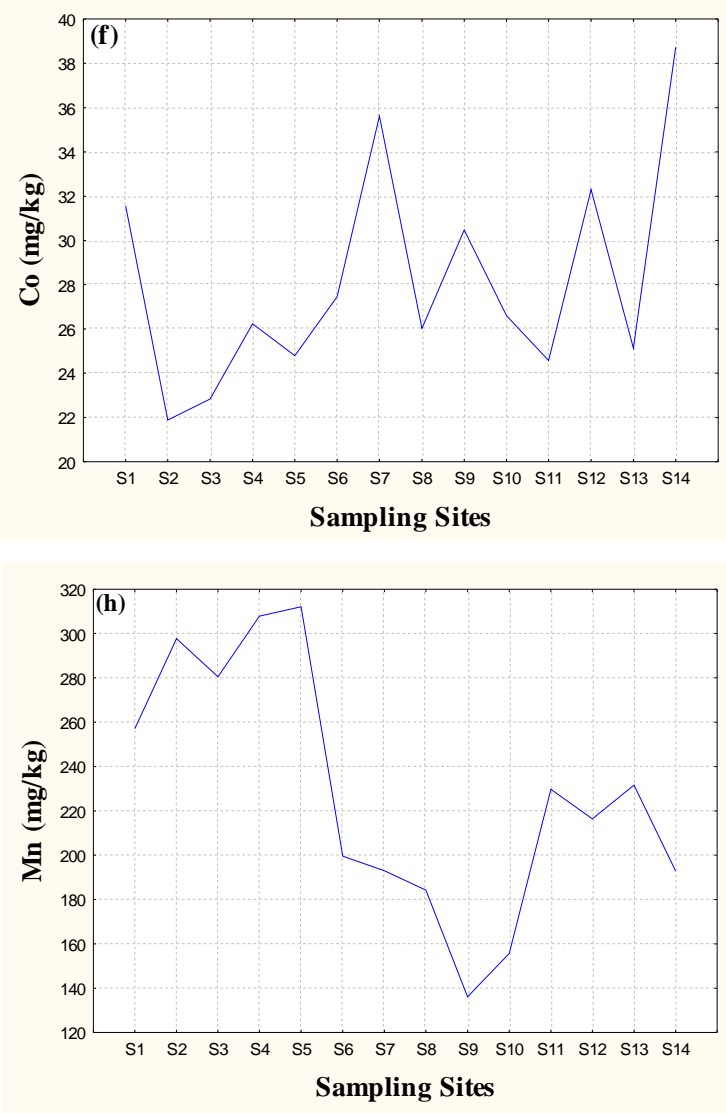


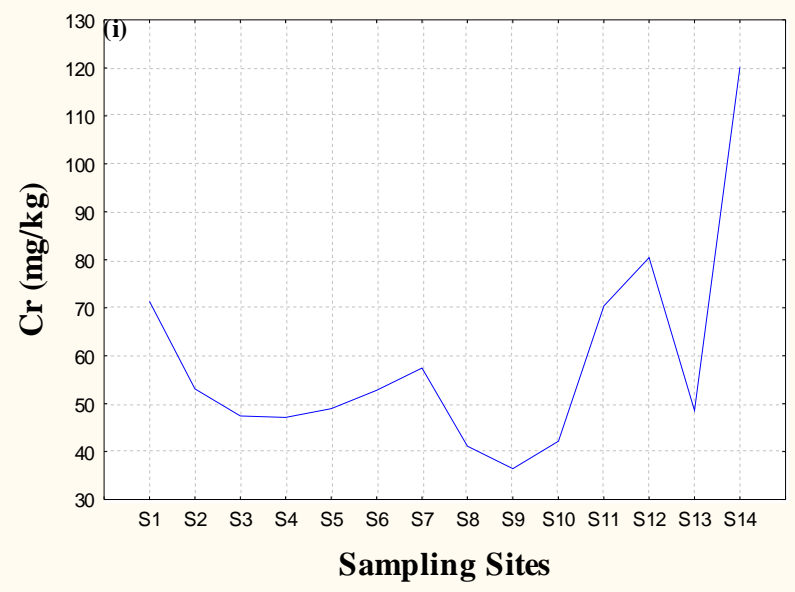

Figure 4. Spatial variation of heavy metals in Euphrates River sediments.

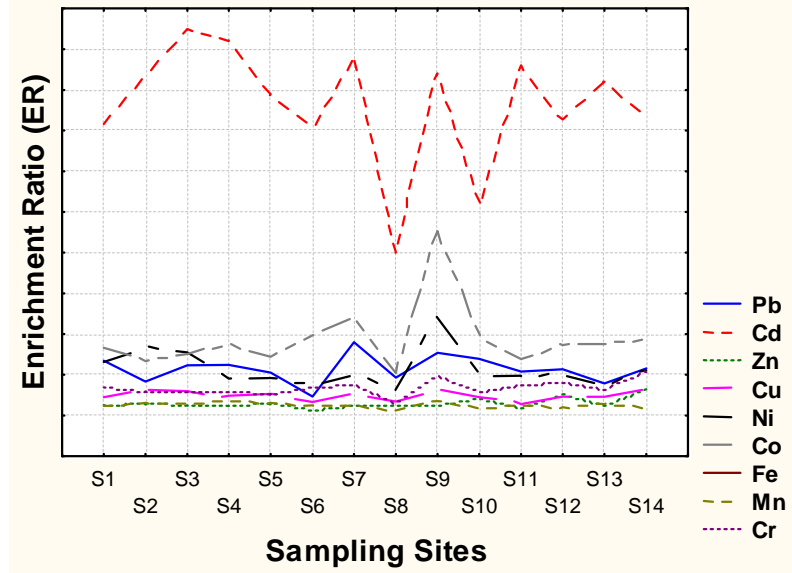

Figure 5. Enrichment ratio (ER) of heavy metals in Euphrates River sediments.

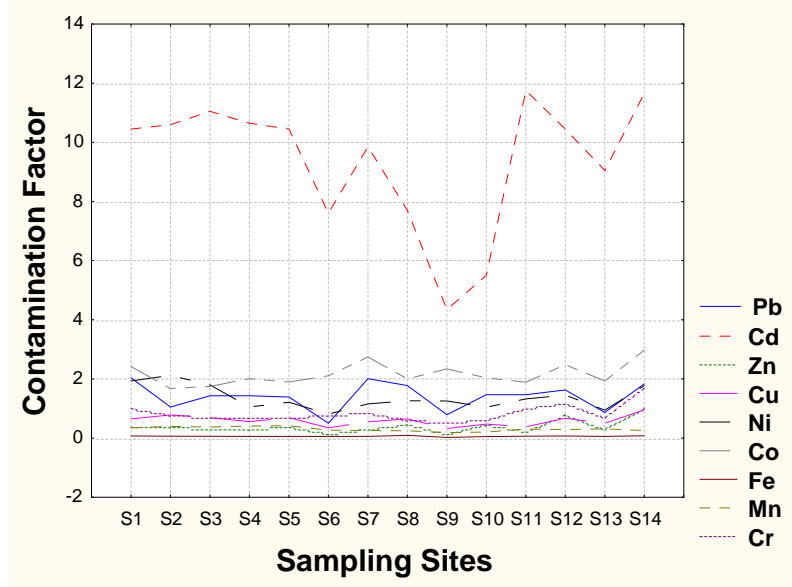

Figure 6. Contamination factor (CF) of heavy metals In Euphrates River sediments.

irrigation water, rich in phosphate fertilizers, to the river and discharging untreated municipal heavy water to the river without treatment from highly populated cities.

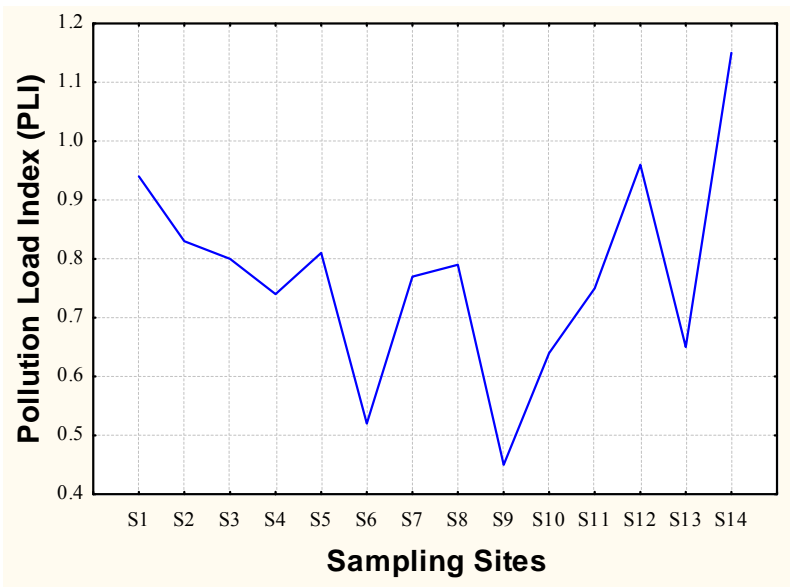

Figure 7. Pollution load index values of sampling sites at Euphrates River.

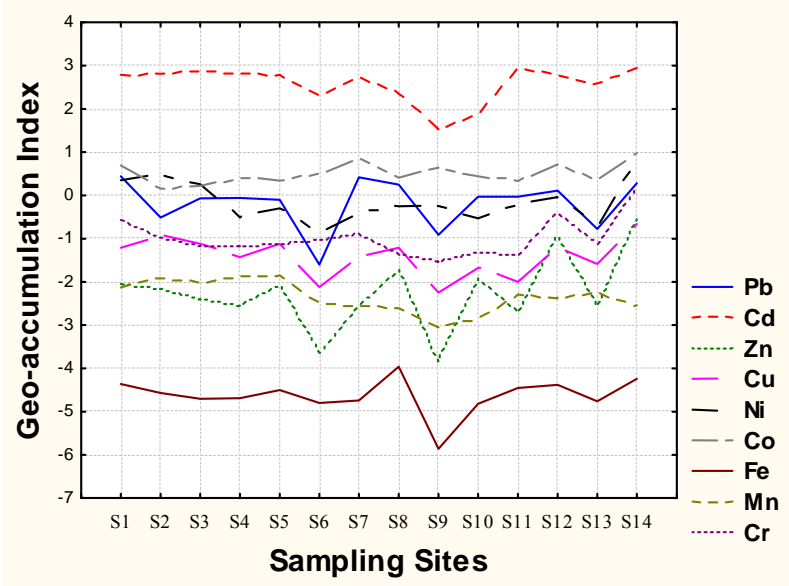

Figure 8. Geo-accumulation indices (GIs) of heavy Metals in Euphrates River sediments.

The EF values for $\mathrm{Cd}$ in the Euphrates River Sediments varied between 80.70 to 189.95 . The EF values of $\mathrm{Cd}$ were greater than 40 for all sampling sites, suggesting 
that these sites are classified as extremely high enrichment (Table 8). The EF values for $\mathrm{Cd}$ in two stations in Heet and Ramadi cites are 8.60 and 5.80, respectively [15]. They classified these stations as significant enrichment for Cd.

The contamination factor $(\mathrm{CF})$ values for $\mathrm{Cd}$ varied from 5.5 at $\mathrm{S} 10$ to 11.75 at $\mathrm{S} 12$ with a mean value of 9.36 (Table 9). All sampling sites has more than $6(<6)$ except S10 less than $6(6>)$. According to [31], all sampling sites were very high contaminated by $\mathrm{Cd}$ except S10 faces considerable contamination.

The $\mathrm{I}_{\text {geo }}$ values for $\mathrm{Cd}$ in Euphrates River sediments ranged from 1.53 to 2.96. All sampling sites has $I_{\text {geo }}$ for Cd more than 2 and less than $3\left(2<\mathrm{I}_{\text {geo }}<3\right)$ except sites S9 and S10 more than 1 and less than $2\left(1<\mathrm{I}_{\mathrm{geo}}<2\right)$. According to Muller's classification (Table 4), the $I_{\text {geo }}$ values for $\mathrm{Cd}$ indicate that Euphrates River sediments are moderately to strongly polluted for most sampling sites and moderately polluted for S9 and S10. Rabee et al. [15] found that the $\mathrm{I}_{\text {geo }}$ values for $\mathrm{Cd}$ in the Euphrates River stations (Heet and Ramadi cities) indicate the sediments were unpolluted to moderately polluted.

$\mathrm{Zn}$ concentration ranged between 14.96 and 130.25 $\mathrm{mg} / \mathrm{kg}$. The mean value was $48 \mathrm{mg} / \mathrm{kg}$. It was less than the world surface rock average and the mean shale background concentration as a geochemical background level (Table 5). In comparison, it was found that $\mathrm{Zn}$ mean value was below WHO, USEPA and CCME guidelines. According to sediment quality guidelines, Euphrates River sediments were unpolluted by $\mathrm{Zn}$. Zn expressed strong positive correlation with $\mathrm{Cu}$ and $\mathrm{Cr}$, and good positive correlation with $\mathrm{Co}$ and $\mathrm{Fe}$ at 0.05 level. There are not clear differences in $\mathrm{Zn}$ concentration between winter and spring, Figure 3(c). Zn concentration varies between 14.96 at S9 and 130.25 at S14, Figure 4(c). High values of $\mathrm{Zn}$ concentration were reported at S8 and $\mathrm{S} 12$. $\mathrm{Zn}$ concentration at S14 was more than sediment quality guidelines (Table 5). This indicates that Euphrates River sediments at S14 was polluted by Zn due to sewage water in Ramadi city. In comparison with previous studies (Table 7), We found that $\mathrm{Zn}$ concentration recorded in this study was near to that estimated by [14] and less than that assessed by $[16,23,29]$.

The enrichment factor (EF) values for $\mathrm{Zn}$ in Euphrates River sediments ranged from 2.43 at S6 to 12.9 at S14. The EF values for majority of sampling sites were greater than 2 and less than 5 (Table 8), suggesting that these sites are classified as moderate enrichment for $\mathrm{Zn}$. The other sites, S1, S2, S5, S10, S12, and S14) are classified as significant enrichment. These sites are in or near the township area.

The CF values for $\mathrm{Zn}$ in the Euphrates River sediments varied from 0.11 at S9 and 1.02 at $\mathrm{S} 14$ with mean value of 0.37 (Table 9). Most sampling sites has CF less than 1 except S14 more than 1. It was found that most sampling sites were classified as low contaminated and S14 faces moderate contamination.

The $\mathrm{I}_{\text {geo }}$ values for $\mathrm{Zn}$ in all sampling sites were less than $0(<0)$, Table 10. These negative values indicate that the Euphrates River sediments in the study area are unpolluted by $\mathrm{Zn}$.

$\mathrm{Cu}$ concentration varied from 10.35 to $30.52 \mathrm{mg} / \mathrm{kg}$ and $18.91 \mathrm{mg} / \mathrm{kg}$ mean concentration was found. Mean value was less than the world surface rock average and more than mean shale concentration as geochemical background level (Table 5). In comparison with sediment quality guidelines, the mean value did not exceed the WHO and CCME guidelines and exceeded the USEPA guidelines. According to USEPA, Euphrates River sediments have little pollution by $\mathrm{Cu}$. $\mathrm{Cu}$ correlated significantly with $\mathrm{Ni}$ and $\mathrm{Fe}$ at 0.05 level. It has also good positive correlations. Due to correlations, these metals have common source.

$\mathrm{Cu}$ concentration mean was near to that reported by [14] for the same studied area and less than that estimated by [15] for downstream region of the study area. Al-Bassam and Al-Mukhtar [29] reported $\mathrm{Cu}$ concentration for number of sites in the study area, greater than recorded in this study. $\mathrm{Cu}$ mean value was also less than that of the world rivers average [23].

Higher concentration of $\mathrm{Cu}$ was found during spring than winter (Figure 3(d)). S14 showed higher concentration of $\mathrm{Cu}(30.52 \mathrm{mg} / \mathrm{kg})$ and lowest concentration was $10.35 \mathrm{mg} / \mathrm{kg}$ at S9, Figure 4(d). We found high concentrations for $\mathrm{Cu}$ at sites located in and near the population centers.

The enrichment factor (EF) values for $\mathrm{Cu}$ in Euphrates River sediments vary from 5.61 at $\mathrm{S} 11$ to 12.50 at S9 (Table 8). All sampling sites has EF values more than 5 and less than 20, suggesting that Euphrates River sediments are classified as significant enrichment for $\mathrm{Cu}$. Rabee et al. [15] reported values for EF less than that estimated in this study for two sites in the downstream region of the study area.

The contamination factor $(\mathrm{CF})$ for $\mathrm{Cu}$ in Euphrates River sediments ranged from 0.32 at $\mathrm{S} 9$ to 0.95 at $\mathrm{S} 14$ with a mean value of 0.58 . The $\mathrm{CF}$ values for $\mathrm{Cu}$ were less than $1(<1)$ at all sampling sites. According to [31], all sampling sites face low contamination by $\mathrm{Cu}$.

The $\mathrm{I}_{\text {geo }}$ values for $\mathrm{Cu}$ at the sampling sites were negative. According to Muller's classification, Euphrates River sediments at all sampling sites were unpolluted. This result was in good agreement with results of [15].

The concentration of $\mathrm{Ni}$ value was between 39.98 and $103.98 \mathrm{mg} / \mathrm{kg}$. Mean concentration was $67.08 \mathrm{mg} / \mathrm{kg}$. Mean value greater than world surface rock average and less than mean shale concentration as background level. According to WHO and USEPA guidelines, Ni concen- 
tration mean exceeded the guidelines suggesting that Euphrates River sediments are polluted by Ni. The seasonal variation of Ni is shown in Figure 3(e). Ni concentrations of Euphrates River sediments vary between $39.98 \mathrm{mg} / \mathrm{kg}$ at $\mathrm{S} 6$ and $103.98 \mathrm{mg} / \mathrm{kg}$ at $\mathrm{S} 2$, Figure 4(e). High concentrations were recorded at sampling sites in and near urbanization centers such as AlQaim (S1, S2, S3), Heet (S11, S12) and Ramadi (S14). In comparison with previous studies, $\mathrm{Ni}$ concentration mean value was less than reported by $[14,29]$, Table 7 . It was also more than estimated by [15]. Ni mean value was less than world rivers average.

The enrichment factor (EF) values for Ni in Euphrates River sediments range from 13.15 at $\mathrm{S} 8$ to 48.40 at $\mathrm{S} 9$, Table 8. Some sampling sites (S4, S5, S6, S8, S10, S11 S13) have EF for Ni more than 5 and less than 20. The Euphrates River sediments in as significant enrichment for Ni. Other sampling sites (S1, S2, S3, S7, S12, S14) have EF values for Ni more than 20 and less than 40 suggesting that Euphrates River sediments are classified as very high enrichment for Ni. Euphrates River sediments at S9 are classified as extremely high enrichment for Ni. Rabee et al. [15] classified Euphrates River sediments at two stations in Heet and Ramadi cities as moderately polluted for $\mathrm{Ni}$.

The contamination factor (CF) values for Ni in Euphrates River sediments ranged from 0.81 at $\mathrm{S} 6$ to 2.12 at S2, with mean value of 1.36 . Most sampling sites except $\mathrm{S} 6$ and S13 have CF more than 1 and less than 3. According to [31], most sampling sites are moderately contaminated and S6 and S13 face low contamination by Ni.

The $\mathrm{I}_{\text {geo }}$ values for $\mathrm{Ni}$ at all sampling sites were negative except S1, S2, S3, and S14 were positive. According to Muller's classification, Euphrates River sediments were unpolluted at most sites and from unpolluted to moderately polluted at other sites. This result was in good agreement with that of [15] for station at Heet city.

Co concentration ranged between 21.88 and 38.73 $\mathrm{mg} / \mathrm{kg}$. The mean value was 28.16 and $38.73 \mathrm{mg} / \mathrm{kg}$. The mean value was $28.16 \mathrm{mg} / \mathrm{kg}$. The general acceptance of Co is $4-20 \mathrm{mg} / \mathrm{kg}$ [3]. The mean value of Co concentration was more than the world surface rock average and near to the mean shale concentration as geochemical background level, Table 5. Co showed strong positive correlation with $\mathrm{Cr}$ at 0.05 level. Co concentrations in the sediments were highest during the winter than the spring, Figure 3(f). Spatial variation of Co concentration was given in Figure 4(f), and the maximum value was 38.73 $\mathrm{mg} / \mathrm{kg}$ at S14 while the minimum value was $21.88 \mathrm{mg} / \mathrm{kg}$ at S2. As well as S14, high values were reported at S1, S7, S9 and S12. These sites locate in and near the urbanization centers, such as AlQaim, Haditha, Heet and Ramadi. The Co concentration value was less than that reported by $[23,29]$. It was also more than that the region located at the downstream region of the study area [16].

The EF values for Co in Euphrates River sediments were from 20.88 at S8 and 90.60 at S9, Table 8. Most sampling sites have EF for Co more than 20 and less than 40, while S7 and S9 more than 40. According to Mmolawa et al. [12], Euphrates sediments at sampling sites are classified as very high to extremely high enrichment for Co.

The CF values for Co in Euphrates River sediments ranged from 1.68 at $\mathrm{S} 2$ to 2.74 at $\mathrm{S} 7$, with mean value of 2.16. At all sampling sites, the CF values for Co were more than 1 and less than 3. According to [31], all sampling sites were moderately contaminated by Co.

The $\mathrm{I}_{\mathrm{geo}}$ values for Co at all sampling sites vary from 0.16 at S2 to 0.98 at S14, Table 10. According to Muller's classification, Euphrates sediments were from unpolluted to moderately polluted at all sampling sites.

The concentration of $\mathrm{Fe}$ in Euphrates River sediments varied from $928.7 \mathrm{mg} / \mathrm{kg}$ to $3441.05 \mathrm{mg} / \mathrm{kg}$ and mean value was $2249.47 \mathrm{mg} / \mathrm{kg}$. The Fe mean value was less than world surface rock average and mean shale concentration as background level, Table 5. The mean value of $\mathrm{Fe}$ exceeded the USEPA sediment quality guidelines. Generally, during the spring, higher concentrations of $\mathrm{Fe}$ were observed, Figure 3(g). Spatially, concentration of $\mathrm{Fe}$ in Euphrates River sediments ranged from 928.7 $\mathrm{mg} / \mathrm{kg}$ at $\mathrm{S} 9$ to $3441.05 \mathrm{mg} / \mathrm{kg}$ at S8, Figure $\mathbf{4}(\mathrm{g})$. Fe concentration of Euphrates sediments was less than of the world rivers average [23] and more than that reported by [16].

The contamination factor (CF) values for $\mathrm{Fe}$ in Euphrates River sediments ranged from 0.025 at $\mathrm{S} 9$ to 0.095 at $\mathrm{S} 8$, with a mean value of 0.062 . Because of the $\mathrm{CF}$ values for $\mathrm{Fe}$ in all sampling sites less than 1, Euphrates River Sediments face low contamination by Fe.

The $\mathrm{I}_{\text {geo }}$ values for $\mathrm{Fe}$ at all sampling sites were negative. According to Muller's classification, Euphrates sediments were unpolluted by Fe.

Mn concentration ranged between 136.05 and 312.11 $\mathrm{mg} / \mathrm{kg}$ and mean value was $228.18 \mathrm{mg} / \mathrm{kg}$. The mean value of $\mathrm{Mn}$ was less than world surface rock average and shale concentration as geochemical background level, Table 5. Mn mean value exceeded USEPA sediment quality guidelines. Except S8 and S9, others showed higher values during winter than spring, Figure 3(h). The concentration of $\mathrm{Mn}$ at S4 was the highest with value of $307.9 \mathrm{mg} / \mathrm{kg}$ and the lowest concentration was at S9 with a value of $136.05 \mathrm{mg} / \mathrm{kg}$, Figure 4(h). Mn concentration was less than that reported in the local previous studies and the world rivers average, Table 6.

The enrichment factor (EF) values for Mn ranged from 2.56 at $\mathrm{S} 8$ and 7.09 at S4, Table 8. The EF values for Mn at majority of sampling sites (S1, S6, S7, S8, S10, S11, S12 and S14) were greater than 2 and less than 5. At 
these sites, Euphrates River sediments are classified as moderate enrichment for Mn. Other sampling sites (S2, S3, S4, S5, S9, and S13), the EF values were more than 5 and less than 20 and Euphrates sediments are classified as significant enrichment for Mn.

The contamination factor $(\mathrm{CF})$ values for $\mathrm{Mn}$ in $\mathrm{Eu}-$ phrates sediments varied from 0.181 at $\mathrm{S} 9$ to 0.416 at S5, Table 9. At all sampling sites, the CF values were less than 1. According to [31], Euphrates sediments at all sampling sites were low contaminated. The $\mathrm{I}_{\text {geo }}$ values for $\mathrm{Mn}$ at all sampling sites were negative. According to Muller's classification, Euphrates sediments are unpolluted by Mn.

$\mathrm{Cr}$ concentration varied between 36.45 and 120.11 $\mathrm{mg} / \mathrm{kg}$. The mean value was $58.4 \mathrm{mg} / \mathrm{kg}$. It was less than world surface rock average and mean shale concentration as geochemical background level, Table 5. In comparison, it was found that $\mathrm{Cr}$ mean value exceeded WHO, USEPA and CCME Sediment guidelines. With except of S1, S4, S12 and S14, highest concentration of Cr was observed in spring than winter, Figure 3(i). The highest concentration of Cr was observed at S14 (120.11 mg/kg). while the lowest concentration was $36.45 \mathrm{mg} / \mathrm{kg}$ at $\mathrm{S} 9$, Figure 4(i). The high values of $\mathrm{Cr}$ was at township area. $\mathrm{Cr}$ concentration mean was less than that estimated by [29] for Euphrates River and the world rivers average [23].

The EF values for $\mathrm{Cr}$ in Euphrates sediments ranged from 6.04 at $\mathrm{S} 8$ to 21.28 at $\mathrm{S} 14$. All sampling sites have EF more than 5 and less than 20, except S14 has more than 20, Table 8. Euphrates sediments at all sampling sites are classified as significant to very high enrichment for $\mathrm{Cr}$.

The $\mathrm{CF}$ values for $\mathrm{Cr}$ in Euphrates sediments varied from 9.87 at S9 to 22.21 At S14 with mean value of 16.36, Table 9. At all sampling sites, the $\mathrm{CF}$ values were greater than 6 , suggestion that sediments were very high contamination.

The $\mathrm{I}_{\mathrm{geo}}$ values for $\mathrm{Cr}$ at all sampling sites were negative except S14 was positive. According to Muller's classification, Euphrates sediments were unpolluted by $\mathrm{Cr}$ at all sites except at S14 was from unpolluted to moderate polluted.

The overall total geo-accumulation index (Itot) of the entire study area for different metals were found to be negative, Table 10. This suggests that concentration mean of most heavy metals in Euphrates sediments are lower than world surface rock average.

To effectively compare whether the sampling sites suffer contamination or not, the pollution load index (PLI), was used. PLI values of the analyzed samples ranged from 0.45 to 1.15 with a mean value of 0.69 ,

Figure 8, Table 11. At all sampling sites, the PLI values were less than 1 except S14 was greater than 1. Accord- ing to [25], all sampling sites suggest perfection (or no overall pollution), whereas S14 shows signs of pollution or deterioration of site quality. Relatively high PLI value at S14 (Ramadi city) suggests input from anthropogenic sources.

\section{Conclusions}

To investigate the status of metal contamination in Euphrates River sediments, $\mathrm{Pb}, \mathrm{Cd}, \mathrm{Zn}, \mathrm{Cu}, \mathrm{Ni}, \mathrm{Co}, \mathrm{Fe}, \mathrm{Mn}$ and $\mathrm{Cr}$ concentrations were estimated in Fourteen sampling sites. The order of the mean concentrations of tested heavy metals: $\mathrm{Fe}>\mathrm{Mn}>\mathrm{Ni}>\mathrm{Cr}>\mathrm{Zn}>\mathrm{Co}>\mathrm{Pb}>$ $\mathrm{Cu}>\mathrm{Cd}$. The correlation analysis of mean concentrations showed good to strong positive correlations among $\mathrm{Pb}$, $\mathrm{Cd}, \mathrm{Zn}, \mathrm{Ni}, \mathrm{Co}, \mathrm{Fe}, \mathrm{Mn}$ and $\mathrm{Cr}$, suggesting that these metals have common sources.

International sediment quality guidelines (WHO, USEPA and CCME), enrichment factor (EF), contamination factor $(\mathrm{CF})$, geo-accumulation index $\left(\mathrm{I}_{\mathrm{geo}}\right)$ and pollution load index (PLI) were applied for assessment of contamination. According to sediment quality guidelines, Euphrates sediments were polluted by $\mathrm{Cd}, \mathrm{Cu}, \mathrm{Ni}, \mathrm{Fe}$, $\mathrm{Mn}$ and $\mathrm{Cr}$. The EF values suggest that Euphrates sediments were very high enriched for $\mathrm{Pb}$, extremely high for $\mathrm{Cd}$, moderately for $\mathrm{Zn}$, significantly for $\mathrm{Cu}$, significantly to very high for $\mathrm{Ni}$, very high to extremely high for $\mathrm{Co}$, moderately to significantly for $\mathrm{Mn}$ and significantly to very high for $\mathrm{Cr}$. According to $\mathrm{CF}, \mathrm{Cd}$ and $\mathrm{Cr}$ are responsible for very high contamination. The $\mathrm{I}_{\text {geo }}$ values showed that Euphrates sediments quality was moderately to strongly polluted for CD. According to PLI, all sites suggest perfection or no overall pollution of site quality. In general, $\mathrm{I}_{\text {tot }}$ indices for most heavy metals were negative; this implies that mean concentration of heavy metals Euphrates sediments are lower than world surface rock average. Considering all assessing criteria, $\mathrm{Cd}$ is responsible for significant amount of heavy metal contamination, while $\mathrm{Co}$ and $\mathrm{Cr}$ are responsible for moderate to high contamination. S14 (Ramadi city) contains highest amount of heavy metals contamination and S9 (Hajlan) contains lowest amount of heavy metal contamination.

\section{REFERENCES}

[1] F. Abbas, I. A. Norli, A. Aness and E. Azharmat, "Analysis of Heavy Metal Concentrations in Sediments of Selected Estuaries of Malaysia-A Statistical Assessment," Environmental Monitoring and Assessment, Vol. 153, No. 1-4, 2009, pp.179-185. doi:10.1007/s10661-008-0347-x

[2] R. Bettinentti, C. Giarei and A. Provini, "A Chemical Analysis and Sediment Toxicity Bioassays to Assess the Contamination of River Lambro (Northern Italy)," Archives of Environmental Contamination and Toxicology, Vol. 45, 
No. 1, 2003, pp. 72-78. doi:10.1007/s00244-002-0126-6

[3] K. V. Raju, R. Somashekar and K. Prakash, "Heavy Metal Status of Sediment in River Cauvery, Karnataka," Environmental Monitoring and Assessment, Vol. 184, No. 1, 2012, pp. 361-373. doi:10.1007/s10661-011-1973-2

[4] M. Chakravarty and A. Patgiri, "Metal Pollution Assessment in Sediments of the Dikrong River, N. E. India," Journal of Human Ecology, Vol. 27, No. 1, 2009, pp. 63-67.

[5] S. Olivares-Rieumont, D. de la Rosa, L. Lima, D. Graham, K. Alessandro, J. Borroto, et al., "Assessment of Heavy Metal Levels in Almendares River Sediments-Havana City, Cuba," Water Research, Vol. 39, No. 16, 2005, pp. 3945-3953. doi:10.1016/j.watres.2005.07.011

[6] I. Brunner, J. Luster, M. Günthardt-Goerg and B. Frey, "Heavy Metal Accumulation and Phytostabilisation Potential of Tree Fine Roots in a Ccontamination Soil," Environmental Pollution, Vol. 152, No. 3, 2008, pp. 559568. doi:10.1016/j.envpol.2007.07.006

[7] A. Idris, M. A. H. Eltayeb, S. Potgieter-Vermaak, R. Van Grieken and J. Potgieter, "Assessment of Heavy Metals Pollution in Sudanese Harbors along the Red Sea Coast," Microchemical Journal, Vol. 87, No. 2, 2007, pp.104-112. doi:10.1016/j.microc.2007.06.004

[8] S. Morin, T. Duong, A. Danbrin, A. Coynel, O. Herlory, M. Baudrimont, et al., "Long-Term Survey of HeavyMetal Pollution, Biofilm Contamination and Diatom Community Structure in the Rio Mort Watershed, SouthWest France," Environmental Pollution, Vol. 151, 2008, pp. 532-542. doi:10.1016/j.envpol.2007.04.023

[9] A.-P. Zhong, S.-H. Guo, F.-M. Li, G. Li and K.-X. Jiang, "Impact of Anions on the Heavy Metals Release from Marine Sediments," Journal of Environmental Sciences, Vol. 18, No. 6, 2006, pp. 1216-1220. doi:10.1016/S1001-0742(06)60065-X

[10] C. Atkinson, D. Jolley and S. Simpson, "Effect of Overlying Water $\mathrm{pH}$, Dissolved Oxygen, Salinity and Sediment Disturbances on Metal Release and Sequestration from Metal Contaminated Marine Sediments," Chemosphere, Vol. 69, No. 9, 2007 , pp. 1428-1437. doi:10.1016/j.chemosphere.2007.04.068

[11] P. Harikumar and T. Jisha, "Distribution Pattern of Trace Metal Pollutants in the Sediments of an Urban Wetland in the Southwest Coast of India," International Journal of Engineering Science and Technology, Vol. 2, No. 5, 2010, pp. 840-850.

[12] K. Mmolawa, A. Likuku and G. Gaboutloeloe, “Assessment of Heavy Metal Pollution in Soils along Roadside Areas in Botswana," African Journal of Environmental Science and Technology, Vol. 5, No. 3, 2011, pp. 186196.

[13] Y. Wang, Z. Yang, Z. Shen, Z. Tang, J. Niu and F. Gao, "Assessment of Heavy Metals in Sediments from a Typical Catchment of the Yangtze River, China," Environmental Monitoring and Assessment, Vol. 172, No. 1-4, 2011, pp. 407-417.

[14] T. Kassim, H. Al-Saadi, A. Al-Lami and H. Al-Jaberi, "Heavy Metals in Water, Suspended Particles, Sediments and Aquatic Plants of the Upper Region of Euphrates River, Iraq," Journal of Environmental Science and Health, Vol. 32, No. 9-10, 1997, pp. 2497-2506. doi: $10.1080 / 10934529709376698$

[15] A. Rabee, Y. Al-Fatlawy and A. Abd Own, "Seasonal Variation and Assessment of Heavy Metal Pollution in Sediments from Selected Stations in Tigris and Euphrates Rivers, Central Iraq," Iraqi Journal of Science, Vol. 50, No. 4, 2009, pp. 466-475.

[16] F. Hassan, M. Saleh and J. Salman, "A Study of Physicochemical Parameters and Nine Heavy Metals in the Euphrates River, Iraq," E-Journal of Chemistry, Vol. 7, No. 3, 2010, pp. 685-692. doi:10.1155/2010/906837

[17] CCME, "Canadian Water Quality Guidelines for Protection of Aquatic Life," Technical Report, Canadian Environmental Quality Guidelines, Canadian Water Quality Index 1.0, 1999.

[18] S. Valeria, C. Smith and A. Donovan, "Microwave Digestion for Sediment, Soil and Urban Particulate Matter for Trace Metal Analysis," Talanta, Vol. 60, No. 4, 2003, pp. 715-723. doi:10.1016/S0039-9140(03)00131-0

[19] H. Feng, X. Han, W. G. Zhang and L. Z. Yu, "A Preliminary Study of Heavy Metal Contamination in Yangtze River Intertidal Zone Due to Urbanization," Marine Pollution Bulletin, Vol. 49, No. 11-12, 2004, pp. 910-915. doi:10.1016/j.marpolbul.2004.06.014

[20] I. Cato, "Recent Sedimentological and Geochemical Conditions and Pollution Problems in Two Marine Areas in Southwestern Sweden," Striae, Vol. 6, 1977, pp. 1-150.

[21] K. Choi, S. Kim, G. Hong and H. Chon, "Distribution of Heavy Metals in the Sediments of South Korean Harbors," Environmental Geochemical Health, Vol. 34, No. 1, 2012, pp. 71-82. doi:10.1007/s10653-011-9413-3

[22] S. Sinex and G. Helz, "Regional Geochemistry of Trace Elements in Chesapeak Bay Sediments," Environmental Geology, Vol. 3, No. 6, 1981, pp. 315-323. doi:10.1007/BF02473521

[23] J. Martin and M. Meybeck, "Elemental Mass-Balance of Material Carried by Major World Rivers," Marine Chemistry, Vol. 7, No. 3, 1979, pp. 178-206. doi:10.1016/0304-4203(79)90039-2

[24] V. Tippie, "An Environmental Characterization of Chesapeak Bay and a Framework for Action," In: V. Kennedy, Ed., The Estuary as a Filter, Academic Press, New York, 1984, pp. 467-487.

[25] D. Tomlinson, J. Wilson, C. Harris and D. Jeffrey, "Problems in the Assessment of Heavy-Metal Levels in Estuaries and the Formation of a Pollution Index," Helgoland Marine Research, Vol. 33, No. 1-4, 1980, pp. 566-575.

[26] G. Muller, "Index of Geoaccumulation in Sediments of the Rhine River," GeoJournal, Vol. 2, No. 3, 1969, pp. 108-118.

[27] G. Muller, "The Heavy Metal Pollution of the Sediments of Neckars and Its Tributary," A Stocktaking Chemische Zeit, Vol. 150, 1981, pp. 157-164.

[28] Z. G. Ya, L. F. Zhou, Z. Y. Bao, P. Gao and X. W. Sun, "High Efficiency of Heavy Metal Removal in Mine Water by Limestone," Chinese Journal of Geochemistry, Vol. 
28, No. 3, 2007, pp. 293-298. doi:10.1007/s11631-009-0293-5

[29] K. Al-Bassam and L. Al-Mukhtar, "Heavy Minerals in the Sediments of the Euphrates River, in Iraq," Iraqi Journal of Geology and Mining, Vol. 4, 2008, pp. 29-41.

[30] K. Al-Bassam, "Environmental Factors Influencing Spatial Distribution of Cadmium in the Euphrates River Sediments in Iraq," Iraqi Journal of Geology and Mining, Vol. 7, 2011, pp. 29-41.

[31] L. Hakanson, "An Ecological Risk Index for Aquatic Pollution Control a Sedimentological Approaches," Water Research, Vol. 14, No. 8, 1980, pp. 975-1001. doi:10.1016/0043-1354(80)90143-8

[32] WHO, "Guidelines for Drinking Water Quality," 3rd Edition, World Health Organization, 2004, p. 515.

[33] USEPA, "US Environmental Protection Agency: Screening Level Ecological Risk Assessment Protocol for Hazardous Waste Combustion facilities," Appendix E: Toxicity Reference Values, Vol. 3, 1999.

[34] A. Al-Juboury, "Natural Pollution by Some Heavy Metals in the Tigris River, Northern Iraq," International Journal of Environmental Research, Vol. 31, No. 2, 2009, pp. 189-
198.

[35] A. Al-Lami and H. Al-Jaberi, "Heavy Metals in Water, Suspended Particles and Sediment of the Upper-Mid Region of Tigris River, Iraq," Proceedings of International Symposium on Environmental Pollution Control and Waste Management, Tunis, 7-10 January 2002, pp. $97-$ 102.

[36] M. Nameer, A. Rabee, A. Abd Own and Y. Al-Fatlawy, "Using Pollution Load Index (PLI) and Geoaccumulation Index $\left(\mathrm{I}_{\mathrm{geo}}\right)$ for Assessment of Heavy Metals Pollution in Tigris River Sediments in Baghdad Region," Journal of Al-Nahrain University-Science, Vol. 14, No. 4, 2011, pp. 108-114.

[37] R. Marathe, Y. Marathe, C. Sawant and V. Shrivastava, "Detection of Trace Metals in Surface Sediment of Tapti River: A Case Study," Archives of Applied Science Research, Vol. 3, No. 2, 2011, pp.472-476.

[38] P. Saha and M. Hossain, "Assessment of Heavy Metal Concentration and Sediment Quality in the Buriganga River, Bangladesh," Internationa Proceedings of Chemi$\mathrm{Cal}_{2}$ Biological and Environmental Engineering, Singapore City, 26-28 February 2010, pp. VI-384 -VI-387. 